\title{
Doctors call to phase out coal-fired electricity
}

$\mathrm{I}$ t's inefficient, it's dirty and it harms both people and the planet. These are among the reasons behind a call by some Canadian physicians and health organizations to accelerate the phase-out of coal-generated electricity. Their call is timely, as first ministers are due to receive recommendations on the issue from a federal working group as soon as Oct. 27, and a first ministers meeting on climate change is due before year's end.

The coalition of 15 health organizations led by the Canadian Association of Physicians for the Environment (CAPE) is urging the federal government to phase out all coal-fired electricity generation in Canada by 2025. The Canadian Medical Association has an even tighter timeline with a 2014 resolution "supporting government efforts to phase out coal-fired electricity generation within a 10 -year time limit."

Coal provides about $11 \%$ of Canada's electricity, but more than $70 \%$ of the greenhouse gases emitted by the electricity sector, says Dr. Joe Vipond, CAPE's spokesman on coal. Put another way: Canada's 15 coal-fired electricity generation plants produce about $25 \%$ of Canada's greenhouse gas emissions from some 560 reporting facilities, according to the Pembina Institute, which provides research and education on climate change.

The previous Canadian government set a target of phasing out $90 \%$ of coal generation by 2020 , though there was little action, said Sara Hastings-Simon, program director at the Pembina Institute. "The new government has not (as far as I or my colleagues know) made a formal declaration on this number," she stated in an email. "They have committed to a North America-wide target of $50 \%$ by 2025." Pembina expects Canada will announce a new target as part of its plan on climate change due in December.

Reducing coal-fired power generation is one of five climate policies essential to international success on

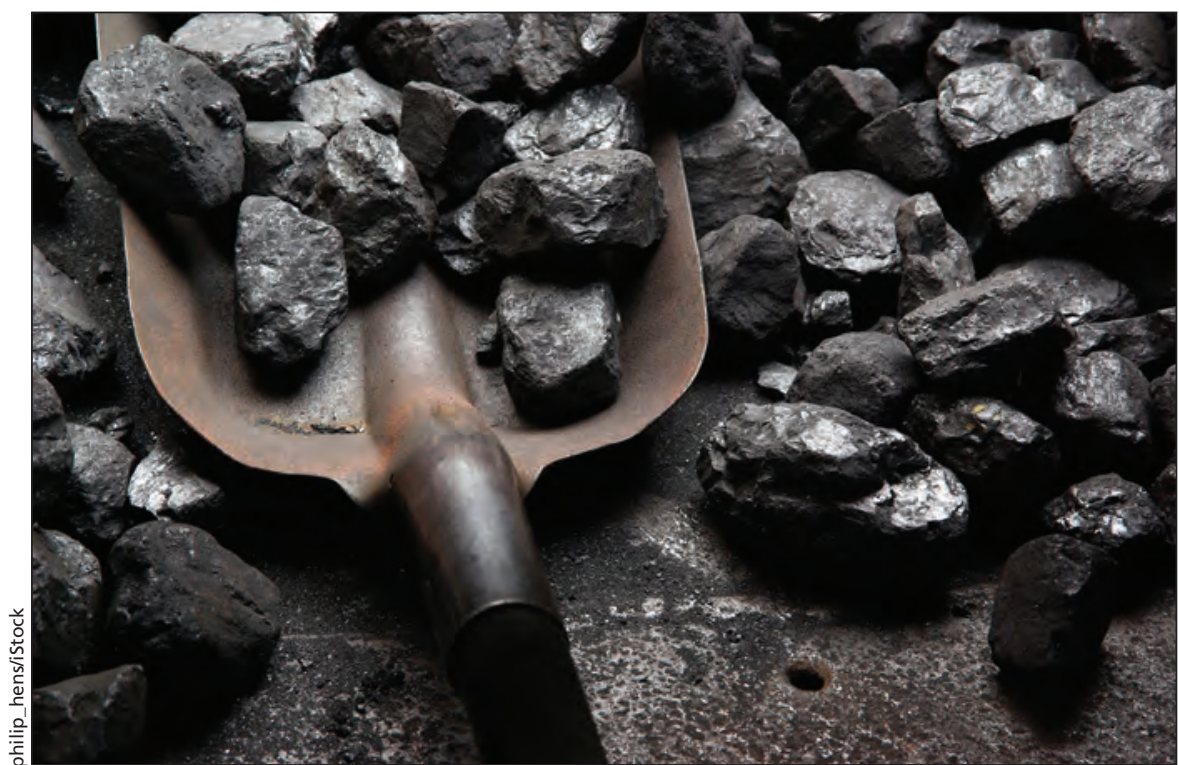

Coal provides about $11 \%$ of Canada's electricity, but more than $70 \%$ of greenhouse gases emitted by the electricity sector.

climate change, states the International Energy Agency. The Netherlands, Denmark and Austria have already set deadlines for phasing out coal-fired electricity generation.

Closer to home, Ontario, which depended on coal for $30 \%$ of its electricity, closed all six of its plants by 2014 . The results included a decrease in smogalert days from a high of 53 to zero. British Columbia, Alberta, Saskatchewan, New Brunswick and Nova Scotia still use coal-fired electricity. BC, however, has banned conventional coal-fired power and requires all electricity generation to have net zero emissions. And on Oct. 19, Alberta announced it will phase out coal-fired electricity by 2030 .

Saskatchewan Premier Brad Wall defended his province's policy to clean up coal-fired power plants rather than shut them down. In an Oct. 18 media release announcing that province's new policy on climate change, Wall pointed out that there are 2400 new coal-fired electrical generating plants planned or under construction worldwide.

"This is why innovation - developing technology that can be used around the world to reduce emissions - is the logical response if we actually want to solve the problem," Wall stated. "In Saskatchewan, we're focused on making a difference in that battle through the development of carbon capture and storage (CCS) that could dramatically reduce the emissions from those 2400 new coal-fired plants."

"Coal is not going away," agreed Robin Campbell, president of the Coal Association of Canada. Germany is opening a new plant; Japan is opening 29.

Toxic emissions are now much lower in some plants, he added. "It's a complicated issue. We need to be able to sit down and come up with real solutions to real problems, rather than the simplistic solution of closing these down."

Every energy source affects the environment, he added. For example, flood bays are created in the wake of hydro-electrical dams, migratory birds are killed by wind-generators, and battery disposal is a problem with solar power. "Coal should not be bearing the brunt of criticism," Campbell said.

In the Liberal government's March 2016 Vancouver Declaration on Clean Growth and Climate Change four working groups were formed to advise 
on how to meet or exceed Canada's 2030 target of a $30 \%$ reduction in greenhouse gases below 2005 emission levels. The CAPE-led health coalition presented a report to the working group on mitigating climate change, which is studying coal. The group will report to provincial and territorial ministers in October.

Those ministers will then make recommendations to first ministers later this fall, said Michael Goeres, executive director, Canadian Council of Ministers of the Environment. Whether provinces act independently or on a national level on coal-fired electricity generation "will undoubtedly be a topic of conversation," he added.

For anyone who is concerned about greenhouse gases, "coal is an easy target," said Vipond, an emergency department physician in Calgary. "It's difficult to grasp that climate change will hurt in the next generation, but the health effects of coal are immediate."

These include myocardial infraction, stroke and exacerbation of asthma. The strongest effects are on the cardio- vascular system because of particulate matter of 2.5 microns or less that enter the blood stream via the lungs. "Most doctors don't know this," says Vipond.

According to the Pembina Institute, the cost of health impacts associated with burning coal in Alberta is nearly $\$ 300$ million a year. The health and social costs of coal-fired electricity add at least 3.6-5 cents per kilowatt-hour, nearly doubling the cost of this source of electricity. - Barbara Sibbald, CMAJ

CMAJ 2016. DOI:10.1503/cmaj.109-5348 